\title{
Downer cow syndrome causing rhabdomyolysis and acute renal failure in a 17-month-old Guzerá heifer
}

\author{
Teresa Souza Alves $^{1}$ (iD) Mariana da Costa Gonzaga ${ }^{1}$ (D) Igor Louzada Moreira $^{1}$ (iD \\ Mizael Machado ${ }^{(D)}$ Davi Emanuel Ribeiro de Sousa ${ }^{2}$ Érica Garcia de Araújo Pinto ${ }^{3}$ (D) \\ Márcio Botelho de Castro ${ }^{(}$José Renato Junqueira Borges ${ }^{1}$ (D) Benito Soto-Blanco (D) $^{(}$ \\ Antônio Carlos Lopes Câmara ${ }^{*}$ (iD
}

\begin{abstract}
${ }^{1}$ Hospital Escola de Grandes Animais, Faculdade de Agronomia e Medicina Veterinária (FAV), Universidade de Brasília (UNB), 70636-200, Brasília, DF, Brasil. E-mail: aclcamara@yahoo.com.br. "Corresponding author.

${ }^{2}$ Laboratório de Patologia Veterinária, Faculdade de Agronomia e Medicina Veterinária (FAV), Universidade de Brasília (UNB), Brasília, DF, Brasil. ${ }^{3}$ Secretaria de Estado da Agricultura, Abastecimento e Desenvolvimento Rural do Distrito Federal, Brasília, DF, Brasil.

${ }^{4}$ Departamento de Clínica e Cirurgia Veterinárias, Escola de Veterinária, Universidade Federal de Minas Gerais (UFMG), Belo Horizonte, MG, Brasil.

ABSTRACT: The downer cow syndrome (DCS) is characterized by an alert cow showing inability or reluctance to stand for 12 hours or more. This paper reported clinical, laboratory, and pathological findings in a Guzerá heifer with rhabdomyolysis, pigmenturia and acute renal failure following DCS. A 17-month-old Guzerá heifer was transported via a 350-km ride in a truck and showed sternal recumbency and severe difficulty in standing and walking. Neurological examination was unremarkable, and the heifer presented normal response to cranial nerves and spinal cord tests. Rectal palpation revealed a 5-month gravid uterus. No other abnormalities were noted in the pelvis or around the coxofemoral joints. Biochemical abnormalities included extremely high muscular enzyme activities (creatine phosphokinase and aspartate aminotransferase) and high creatinine levels. Urinalysis revealed blackish and cloudy urine, proteinuria, and a positive occult blood test. Spinal cord ultrasonography showed no abnormalities. This report highlighted an uncommon clinical presentation (myoglobinuria) and pathological findings in a heifer with DCS as a consequence of severe compressive muscle damage. Practitioners and producers must be aware of the risk of careless road transportation for long distances of cattle, especially obese cows, avoiding unnecessary suffering and expenses due to DCS.
\end{abstract}

Key words: permanent recumbency, myoglobinuria, muscular necrosis, obese cattle.

Síndrome da vaca caída causando rabdomiólise e insuficiência renal aguda em uma novilha Guzerá de 17 meses

RESUMO: A síndrome da vaca caída (SVC) é caracterizada por um bovino alerta que mostra incapacidade ou relutância em permanecer em estação por 12 horas ou mais. O objetivo deste trabalho é relatar os achados clínicos, laboratoriais e patológicos em uma novilha Guzerá com rabdomiólise, pigmentúria e insuficiência renal aguda após a SVC. Uma novilha da raça Guzerá, de 17 meses de idade, foi transportada de caminhão por $350 \mathrm{~km}$ e apresentou decúbito esternal, grande dificuldade para assumir estação e caminhar. O exame neurológico não demonstrou alterações, e a novilha possuía resposta normal aos testes de nervos cranianos e medula espinhal. A palpação retal revelou útero grávido de cinco meses. Nenhuma outra anormalidade foi observada na pelve ou na região das articulações coxofemorais. As anormalidades bioquímicas incluiram atividades de enzimas musculares (creatina fosfoquinase e aspartato aminotransferase) extremamente aumentadas e níveis elevados de creatinina. A urinálise revelou urina enegrecida e turva, proteinúria e teste de sangue oculto positivo. O exame ultrassonográfico da medula espinhal não apresentou anormalidades. Este relato evidencia uma apresentação clínica (mioglobinúria) e achados patológicos incomuns em uma novilha com SVC em consequência de extensa lesão muscular compressiva. Veterinários e produtores devem estar atentos aos riscos do transporte rodoviário descuidado por longas distâncias de bovinos, especialmente vacas obesas, evitando assim sofrimento e despesas desnecessárias decorrentes da SVC.

Palavras-chave: decúbito permanente, mioglobinúria, necrose muscular, obesidade bovina.

Downer cow syndrome (DCS) is defined as the inability and unwillingness of an alert cow to stand for 12 hours or more (COX \& ONAPITO, 1986; COX, 1988; BILODEAU et al., 2018). Other definitions include all nonambulatory cattle (alert or non-alert) that are unable to stand for any duration of time without assistance. Consequently, all recumbent cattle are susceptible to muscular pressure damage, regardless of the initial cause of recumbency (COX,
1988; LABONTÉ et al., 2018). Additionally, rhabdomyolysis is a condition characterized by severe acute myonecrosis. It is mostly associated with exertional myopathies in sport horses (VALBERG, 2018). In other species, the causes of rhabdomyolysis include: hyperthermia, muscle compression, electrolyte imbalances, hormonal, mineral, or metabolic disorders (LLADA et al., 2019). This paper reported the clinical, laboratory, and pathological 
findings in a case of rhabdomyolysis followed by marked pigmenturia and acute renal failure in a 17-month-old Guzerá heifer with DCS.

A 17-month-old high genetic value Guzerá heifer was transported via a 350-km ride in a truck with five other cattle for an exhibition event. On arrival, the heifer was on sternal recumbency (Figure 1A) and presented severe difficulty in standing and walking. All animals from the herd were vaccinated against rabies, clostridia, and foot-and-mouth disease.

Physical examination of the Guzerá heifer revealed obesity (550-kg, 8/10 score), serous nasal discharge, slight dehydration, tachycardia (110 beats per min $[\mathrm{bpm}]$ ), tachypnea (50 breaths per min), a rectal temperature of $39.1{ }^{\circ} \mathrm{C}$, and ruminal and intestinal hypomotility. Neurological examination was unremarkable, and the heifer presented a normal response to cranial nerves and spinal cord tests. The heifer showed difficulty in standing after stimulation, hind limb hyperflexion (Figure 1B), instability, myoclonus, and was lying down after 30-60 seconds. During clinical examination, the heifer presented with blackish urine. Rectal palpation revealed a 5-month gravid uterus. No other abnormalities in the pelvis or coxofemoral joints were noted.

Blood samples were collected daily through jugular venipuncture for hematology (complete blood count and fibrinogen determination) and serum biochemistry (aspartate aminotransferase [AST], gamma-glutamyl transferase [GGT], and creatine phosphokinase [CK] activities, as well as urea and creatinine levels) (Table 1). Hematology revealed a discrete total leukocyte count increase attributed to transport stress since no neutrophilia was present (KRAMER et al., 2000). Biochemical abnormalities included extremely high muscular enzyme activities (CK and AST) and high creatinine levels. Urinalysis revealed blackish and cloudy urine, proteinuria, and a positive occult blood test. Spinal cord ultrasonography revealed no abnormalities. Therefore, laboratory findings combined with physical examination and background information permitted presumptive DCS diagnosis, causing rhabdomyolysis and pigmenturia (myoglobinuria) followed by acute

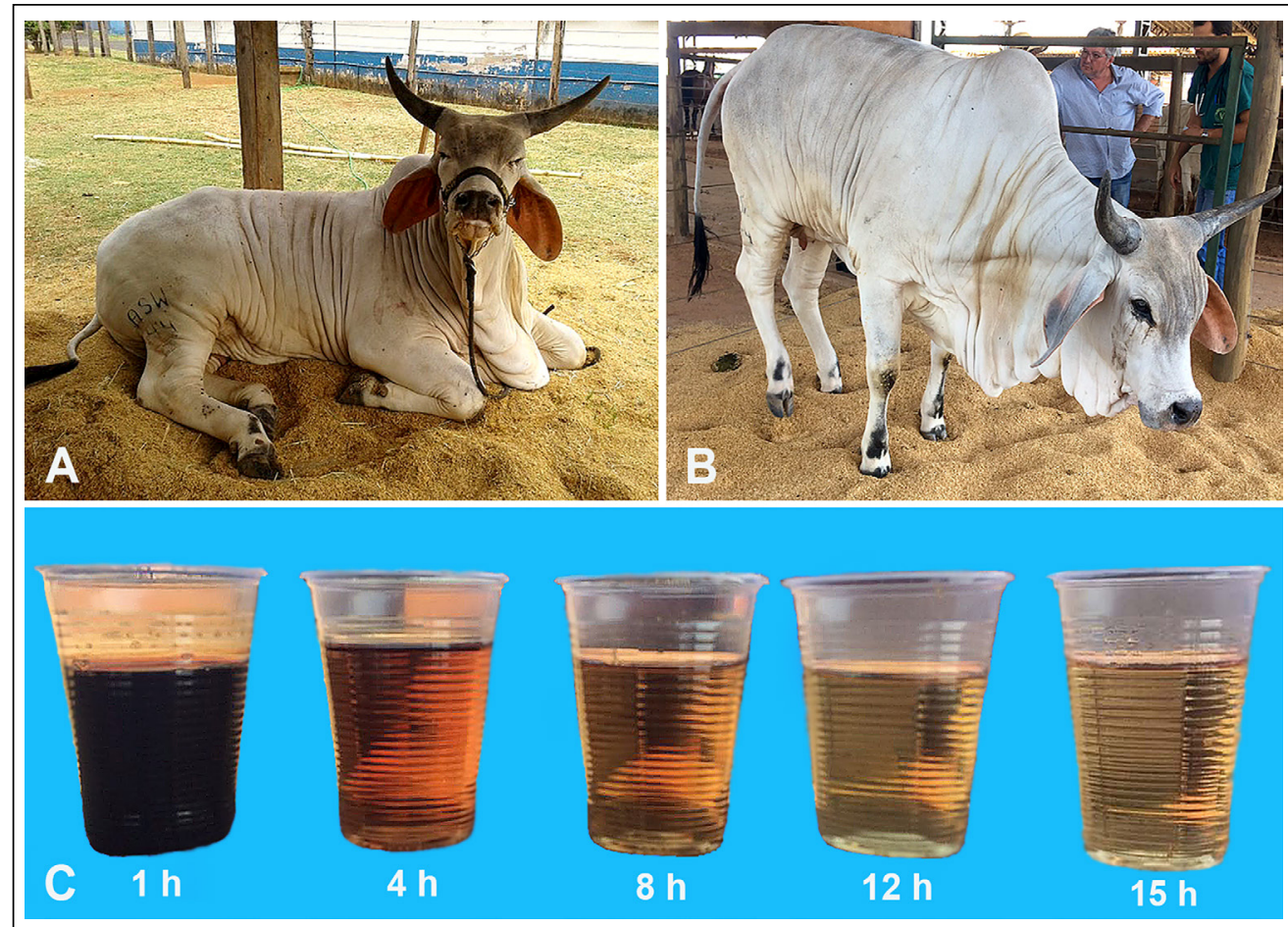

Figure 1 - 17-month-old Guzerá heifer. (A) The animal is alert and on left sternal recumbency. (B) Animal in standing position after stimulation presenting hind limbs hyperflexion and myoclonus. (C) Urine samples clearing over intensive intravenous fluid therapy. 
Table 1 - Serial hematological and biochemical findings in a 17-month-old Guzerá heifer with downer cow syndrome.

\begin{tabular}{|c|c|c|c|c|}
\hline Parameter & -----1 st day---- & ------2nd day---- & ------3rd day---- & ----Reference values ${ }^{*}----$ \\
\hline Hematocrit (\%) & 30 & 29 & - & $24-46$ \\
\hline Red blood cells (x 106/ $\mu \mathrm{L})$ & 7.13 & 7.07 & - & $5-10$ \\
\hline Hemoglobin (g/dL) & 10.2 & 10.1 & - & $8-15$ \\
\hline TPP (g/dL) & 7.2 & 7.2 & 6.4 & $7.0-8.5$ \\
\hline Albumin (g/dL) & 3.1 & 3.5 & 3.9 & $3.03-3.55$ \\
\hline Fibrinogen $(\mathrm{mg} / \mathrm{dL})$ & 600 & 800 & 1,000 & $200-600$ \\
\hline Total leukocytes $(/ \mu \mathrm{L})$ & 13,500 & 13,600 & - & $4,000-12,000$ \\
\hline AST (U/L) & 194 & 761 & 885 & $20-34$ \\
\hline $\mathrm{CK}(\mathrm{U} / \mathrm{L})$ & 11,996 & 49,934 & 57,465 & $4.8-12.1$ \\
\hline GGT (U/L) & 25 & 48 & 59 & $6.1-17.4$ \\
\hline Creatinine $(\mathrm{mg} / \mathrm{dL})$ & 3.2 & 1.6 & 1.3 & $1-2$ \\
\hline Urea (mg/dL) & 20 & 23 & 17 & $42.8-64.2$ \\
\hline
\end{tabular}

TPP: total plasma protein; AST: aspartate aminotransferase; CK: creatine phosphokinase; GGT: gamma glutamyltransferase.

*KRAMER et al., 2000; KANEKO et al., 2008.

renal failure. Intensive care was initiated with continuous intravenous fluids (lactated Ringer's solution), nonsteroidal anti-inflammatory drugs (meloxicam ${ }^{\mathrm{a}}$ : 0.5 mg.kg-1, once a day), and thiamine ${ }^{\mathrm{b}}$ (20 mg.kg ${ }^{-1}$, four times daily) therapy. The heifer was allocated in a stall with the ground covered with high rice litter and kept with Tifton grass and water ad libitum. Every 3-hours, the recumbent side was changed.

The heifer was monitored for 72 hours while receiving intensive intravenous fluid therapy and the aforementioned treatment. The urine gradually cleared over 24 hours (Figure 1C). The heifer tried to stand repeatedly, and after a few hours, the urine became dark again. Clinically, the heifer presented with hyporexia, apathy, and ruminal and intestinal hypomotility. Follow-up laboratory tests which included CK, AST, and GGT showed increased activities (Table 1). On the $3^{\text {rd }}$ day, considering the lack of clinical improvement and poor prognosis, the heifer was humanely euthanized after the owner's consent, and necropsy was performed.

The semitendinosus (Figure 2A), semimembranous (Figure 2B), gracilis, gluteus, tensor fascia lata, supraspinatus, and deep pectoral muscles showed mild to severe lesions (Table 2). These lesions were characterized by multifocal to focally extensive pallor and some areas with white striations or stripes. Histologically, severe monophasic degeneration of myofibers and necrosis (Figure 2C) were major lesions detected in the affected muscle tissues showing hypereosinophilic and homogeneous cytoplasm (hyaline necrosis), loss of striations, pycnosis, or lack of nuclei, or complete muscle cell dissolution (necrosis and cellular debris). Muscle damage areas were surrounded by moderate histiocytic inflammation. Multifocal epithelial tubular cell degeneration and hyaline and myoglobin casts were remarkable in the kidneys (Figure 2D). Gross and histological injury were not detected in other muscle groups, such as gastrocnemius, deltoid, trapezius, longissimus dorsi, psoas, intercostal and diaphragm.

Highly productive and older dairy cows are at great risk of developing DCS, which frequently occurs within 24 hours after calving (COX, 1988; BILODEAU et al., 2018; LABONTÉ et al., 2018). Clinical hypocalcemia, stillbirth, and dystocia were identified as risk factors for DCS in dairy cattle during the first 30 days after parturition (CORREA et al., 1993). DCS is uncommon in a young mid-term pregnant Guzerá heifer. Thus, this report highlighted the relevance of a complete clinical and laboratory evaluation to reach a reliable diagnosis. 


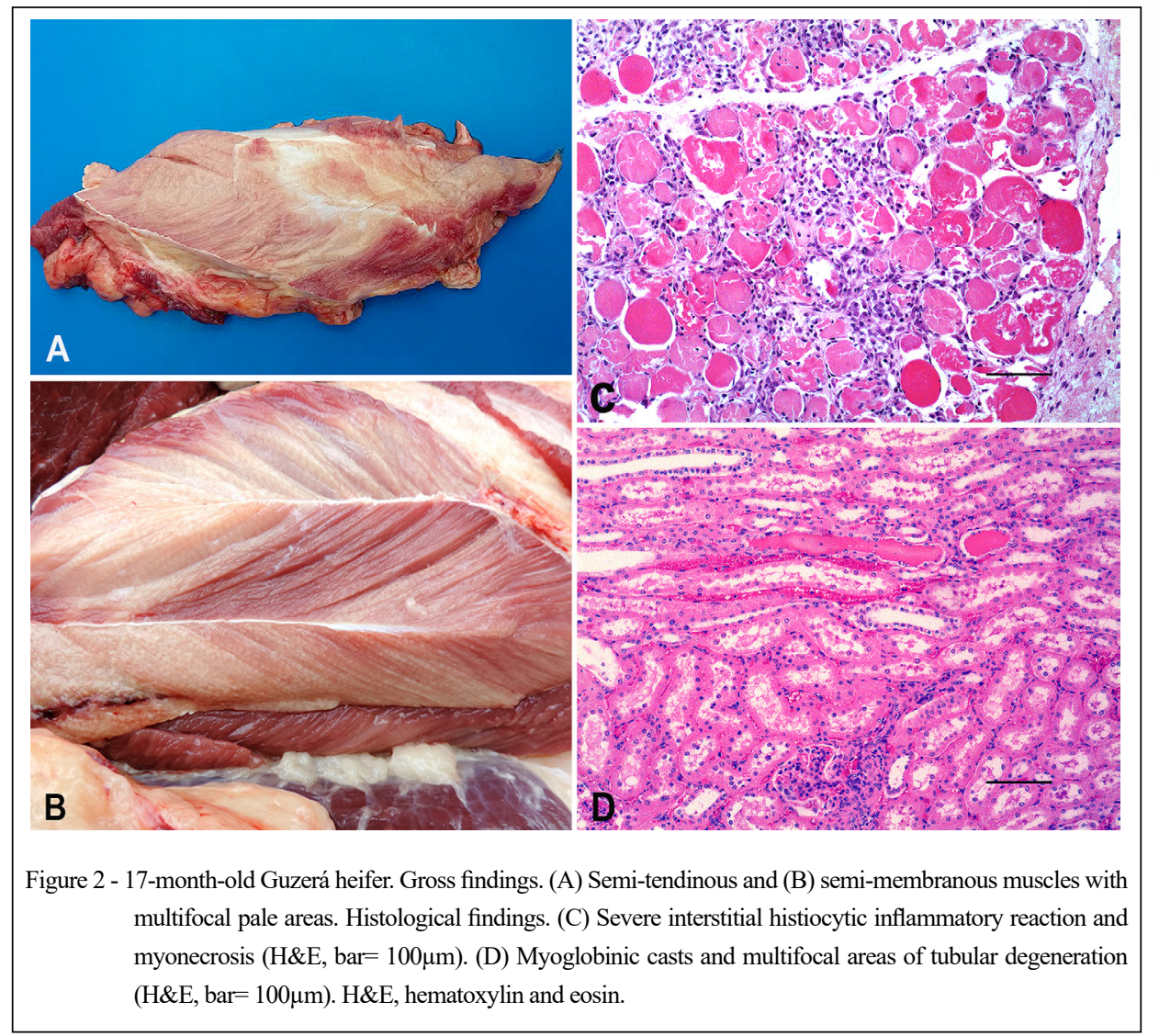

Primary recumbency in cattle presenting with DCS is mostly associated with metabolic, toxicinfectious, traumatic, and neurological disorders, or even iatrogenic causes (COX, 1988). During longride transportation, some harmful situations, such as heat stress, water and food deprivation, and accidental recumbency may occur, thus, increasing the risk of DCS in cattle (COX, 1988). Although, the transportation of the Guzerá heifer lasted only for approximately 5 hours, it occurred during the hottest period of the day. Additionally, experimental studies have suggested that significant pressure damage can occur in the compressed forelimbs as early as 6 hours after sternal recumbency has begun (COX et al., 1982; COX, 1988). Euthanasia has been recommended for nonambulatory cows with more than 24 hours of recumbency (BILODEAU et al., 2018). Therefore, the heifer's overweight condition and non-observance of animals during transportation to avoid recumbency were probably the determinant factors for the development of DCS in this case.

Laboratory ancillary tests provide useful information for determining the origin of pigmenturia (hemoglobinuria or myoglobinuria) (KANEKO et al., 2008; VALBERG, 2018). Biochemical assays (extremely increased CK and AST activities) and urinalyses (presence of proteinuria and occult blood) corroborated the diagnosis of severe muscular damage (KANEKO et al., 2008). These findings strongly suggested myoglobinuria, which confers dark red pigmentation to the urine (LLADA et al., 2019). Consequently, myoglobin exceeds the kidneys' clearance capacity, causing renal damage and acute renal failure (KANEKO et al., 2008; LLADA et al., 2019), as observed by the elevated creatinine level on the day of admission. Severe muscular damage promoted serum elevation of CK activity, massive myoglobin leakage to the bloodstream, and secondary renal failure as observed in the downer Guzerá heifer, which was similar to the hallmark of the "Crush Syndrome" in human beings. This condition is associated with systemic clinical signs related to extensive muscular damage (KIKTA et al., 1987). Recently, cerebrospinal fluid (CSF) analysis was presented as a valiable prognostic tool, in

Ciência Rural, v.52, n.2, 2022. 
Table 2 - Histopathological changes detected in the skeletal muscles of a 17-month-old Guzerá heifer with downer cow syndrome.

\begin{tabular}{|c|c|c|c|c|c|}
\hline \multirow{2}{*}{ Skeletal muscles } & \multicolumn{2}{|c|}{ 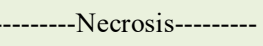 } & \multirow{2}{*}{----Mineralization---- } & \multicolumn{2}{|c|}{----------------Inflammatory Infiltrate------------- } \\
\hline & --HDS-- & --FRG-- & & ------------HT------------ & ------------LP------------ \\
\hline Deep pectoral & +++ & ++ & ++ & +++ & + \\
\hline Supraspinatus & + & - & - & - & - \\
\hline Semitendinosus & + & + & - & + & - \\
\hline Tensor fascia lata & + & + & - & - & - \\
\hline Brachial triceps & - & - & - & - & - \\
\hline Semimembranous & +++ & ++ & + & ++ & + \\
\hline Gracilis & ++ & ++ & - & ++ & + \\
\hline Gluteus & + & + & - & + & - \\
\hline
\end{tabular}

HDS: hyalinization of muscle fibers and disappearance of cross striations; FRG: fragmentation of muscle fibers; HT: histiocytes; LP: lymphocytes. Lesions degree: ${ }^{-}$absent; ${ }^{+}$mild; ${ }^{++}$moderate; ${ }^{++}$severe.

which CSF total nucleated cell count $>4.5$ cells $/ \mu \mathrm{L}$ and protein concentration $>0.39 \mathrm{~g} / \mathrm{L}$ were associated with a poorer short-term survival in downer adult dairy cows (BILODEAU et al., 2018). Additionally, hypertroponinemia $(>0.7 \mathrm{ng} / \mathrm{mL})$ and tachycardia $(>100 \mathrm{bpm})$ were associated with reduced survival in dairy cows affected by DCS (LABONTÉ et al., 2018). Unfortunately, CSF analysis and troponin dosage were not performed, and they might have add essential data reiterating the heifer's euthanasia choice.

The gradual increase in CK and AST activities during the next two days indicated a continuous and active muscle damage process, and was probably due to the heifer's overweight condition and inability to stand. Despite the usefulness of measuring $\mathrm{CK}$ levels, the serum activity is short and may not reflect the ampleness of muscle damage in downer cows (COX et al., 1982). Thiamine supplementation was provided to prevent cell damage mechanisms due to thiamine deficiency, including oxidative stress, excitotoxicity, and inflammation, especially on the liver (APLEY, 2015). Intensive fluid therapy successfully- prevented acute renal failure; however, severe muscular damage impaired the heifer to stand and significantly worsened the prognosis. GGT activity also increased over the days, probably by the onset of hepatic lipidosis, which became a serious concern. This, combined with the poor treatment response and welfare issues reiterated the euthanasia of the heifer as the only option.

Gross findings detected in the necropsy of the Guzerá heifer, such as muscle paleness and some areas with white striations or stripes, reflect the compressive injury in muscle groups and were reported in downer cows worldwide (COX, 1988; COOPER \& VALENTINE, 2015). Muscle paleness and streaking are significant indicators of myofiber necrosis (VALENTINE, 2017). Recumbent cows are susceptible to muscle pressure damage and secondary systemic effects related to vast areas of necrosis (COX, 1981; COX, 1988), such as those presented by the Guzerá heifer.

The compression-associated injury detected in the heifer was characterized histologically by severe monophasic degeneration of myofibers and necrosis in relevant muscle groups of the hind and forelimbs, as well as in the trunk. Monophasic or polyphasic multifocal muscle necrosis varies with the duration of recumbency in the downer cows (VALENTINE, 2017). Hind limbs are considered more susceptible to compression damage because the sternum is well adapted to bear weight during recumbency and protects forelimbs from injury (COX \& ONAPITO, 1986). However, damage to any muscles of the hind limbs, forelimbs, and pectoral muscles may occur in downer cows (VALENTINE, 2017). Compression-induced muscle lesions have been reported in nonambulatory cows affecting the adductor and hamstring regions of the thigh of large muscle masses (COX, 1981), as observed in the Guzerá heifer. Pathological findings in the kidneys and renal failure detected in the downer cow reflected renal tubular damage related to myoglobin deposition (COOPER \& VALENTINE, 2015). 
Multiple etiologies of DCS is a challenge to differential diagnosis and include primary recumbency (milk fever, mastitis/metritis, calving paralysis, and other causes); secondary recumbency (pressure damage of muscles and nerves); and terminal recumbency (struggling damage of muscles and tendons) (COX \& ONAPITO, 1986). Senna occidentalis or S. obtusifolia poisoning (QUEIROZ et al., 2012), ionophore toxicity, nutritional myodegeneration (white muscle disease), clostridial myositis, and sarcosporidiosis should also be included in the differential diagnosis of DCS (ANGELOS et al., 1995; LLADA et al., 2019). The Guzerá heifer was from a high genetic herd with nutritional and veterinary assistance. Therefore, primary and terminal recumbency, ionophore toxicity, nutritional myodegeneration, and Senna poisoning were ruled out after a careful epidemiological background check. Additionally, nutritional myodegeneration presents diffuse segmentar necrosis with calcification, whilst clostridial myositis, and sarcosporidiosis shows specific pathological features, such as intralesional causative infectious agents, that were not detected in this heifer.

Secondary acute renal failure related to rhabdomyolysis and massive myoglobin leakage (myoglobinuria) is uncommon in downer cows, and may lead to clinical misdiagnoses. This report highlights an uncommon clinical presentation and pathological findings in a heifer with DCS as a consequence of severe compressive muscle damage. Practitioners and producers must be aware of the risk of careless road transportation for long distances of cattle, especially obese cows, avoiding unnecessary suffering and expenses due to DCS.

\section{SOURCES OF MANUFACTURES}

a - Maxicam 2\% - Ourofino Saúde Animal Ltda., Cravinho, São Paulo, Brazil.

b - Monovin B1 - Laboratório Bravet Ltda., Engenho

Novo, Rio de Janeiro, Brazil.

\section{ACKNOWLEDGEMENTS}

This work was supported by Conselho Nacional de Desenvolvimento Científico e Tecnológico ( $\mathrm{CNPq})$, and it was financed in part by the Coordenação de Aperfeiçoamento de Pessoal de Nível Superior (CAPES). Brasil - Finance code 001.

\section{BIOETHICS AND BIOSSECURITY COMMITTEE APPROVAL}

We, authors of the article titled "Downer cow syndrome causing rhabdomyolysis and acute renal failure in a 17-month-old Guzerá heifer", declare, for all due purposes, that the project that gave rise to the present data of the same has not been submitted for evaluation to the Ethics Committee of the Universidade de Brasília, but we are aware of the content of the Brazilian resolutions of the National Council for Control of Animal Experimentation -CONCEA "http://www.mct.gov.br/ index.php/content/view/310553.html" if it involves animals. Thus, the authors assume full responsibility for the presented data and are available for possible questions, should they be required by the competent authorities.

\section{DECLARATION OF CONFLICT OF INTERESTS}

The authors declare no conflict of interest.

\section{AUTHORS' CONTRIBUTIONS}

The authors contributed equally to the manuscript.

\section{REFERENCES}

ANGELOS, S. et al. Myophosphorylase deficiency associated with rhabdomyolysis and exercise intolerance in 6 related Charolais cattle. Muscle \& Nerve, v.18, p.736-740, 1995. Available from: $<$ http://dx.doi.org/10.1002/mus.880180710>. Accessed: Feb. 20, 2021. doi: $10.1002 /$ mus. 880180710 .

APLEY, M.D. Consideration of evidence for therapeutic interventions in bovine polioencephalomalacia. Veterinary Clinics of North America: Food Animal Practice, v.31, n.1, p.151-161, 2015. Available from: <https://www.sciencedirect.com/science/ article/pii/S0749072014000851>. Accessed: May. 13, 2021. doi: 10.1016/j.cvfa.2014.11.005.

BILODEAU, M.E. et al. Survival associated with cerebrospinal fluid analysis in downer adult dairy cows: A retrospective study (2006-2014). Journal of Veterinary Internal Medicine, v.32, n.5, p.1780-1786, 2018. Available from: <https://www.ncbi.nlm. nih.gov/pmc/articles/PMC6189354/pdf/JVIM-32-1780.pdf >. Accessed: May. 13, 2021. doi: 10.1111/jvim. 15305.

COOPER, B.J.; VALENTINE, B.A. Muscle and tendon. In: MAXIE, M.G. (Ed.). Jubb, Kennedy \& Palmer's Pathology of Domestic Animals. 6 $6^{\text {th }}$ ed., vol. 1. St. Louis: Elsevier; 2015. p.165-246.

CORREA, M.T. et al. Risk-factors for downer cow syndrome. Journal of Dairy Science, v.76, n.11, p.3460-3463, 1993. Available from: $<\mathrm{https} / / / \mathrm{www}$. sciencedirect.com/science/article/ pii/S0022030293776857>. Accessed: May. 13, 2021. doi: 10.3168/ jds.S0022-0302(93)77685-7.

COX, V.S. Understanding the downer cow syndrome. Compendium: Continuing Education for Veterinarians, v.3, p.472-478, 1981.

COX, V.S. et al. The role of pressure damage in pathogenesis of the downer cow syndrome. American Journal of Veterinary Research, v.43, p.26-31, 1982. Available from: <https://pubmed. ncbi.nlm.nih.gov/6920248>. Accessed: Feb. 20, 2021.

COX, V.S.; ONAPITO, J.S. An update on the downer cow syndrome. Bovine Practitioner, v.21, p.195-199, 1986. Available from: $\quad<$ https://journals.tdl.org/bovine/index.php/bovine/article/ download/1287/1278>. Accessed: Feb. 20, 2021. 
COX, V.S. Nonsystemic causes of the downer cow syndrome. Veterinary Clinics of North America: Food Animal Practice, v.4, n.2, p.413-433, 1988. Available from: <https://www. sciencedirect.com/science/article/abs/pii/S0749072015310574> Accessed: Feb. 20, 2021. doi: 10.1016/s0749-0720(15)31057-4.

KANEKO, J.J. et al. Clinical biochemistry of domestic animals. $6^{\text {th }}$ ed. San Diego: Academic Press; 2008. 928p.

KIKTA,M.J.etal.Crushsyndromeduetolimbcompression.Archives of Surgery, v.122, p.1078-1081, 1987. Available from: <http:/ dx.doi.org/10.1001/archsurg.1987.01400210116019>. Accessed: Feb. 20, 2021. doi: 10.1001/archsurg.1987.01400210116019.

KRAMER, J.W. Normal hematology of cattle, sheep, and goats. In: FELDMAN. B.F. et al. (Eds). Schalm's Veterinary Hematology. $5^{\text {th }}$ ed. Baltimore: Lippincott Williams \& Wilkins; 2000. p.1075-1084.

LABONTÉ, J. et al. Prognostic value of cardiac troponin I and L-lactate in blood of dairy cows affected by downer cow syndrome. Journal of Veterinary Internal Medicine, v.32, n.1, p.484-490, 2018. Available from: <http://dx.doi. org/10.1111/jvim.14874>. Accessed: Feb. 20, 2021. doi: 10.1111/jvim. 14874 .

LLADA, I. et al. Rhabdomyolysis in water buffaloes (Bubalus bubalis). Brazilian Journal of Veterinary Pathology, v.12, n.3, p.139-143, 2019. Available from: <http://dx.doi.org/10.24070/ bjvp.1983-0246.v12i3p139-143>. Accessed: Feb. 20, 2021. doi: 10.24070/bjvp.1983-0246.v12i3p139-143.

QUEIROZ, G.R. et al. Spontaneous Senna obtusifolia poisoning in cattle in the state of Paraná, Brazil. Pesquisa Veterinária Brasileira, v.32, p.1263-1271, 2012. Available from: <http:// dx.doi.org/10.1590/S0100-736X2012001200009>. Accessed: Feb. 20, 2021. doi: 10.1590/S0100-736X2012001200009.

VALBERG, S.J. Muscle conditions affecting sport horses. Veterinary Clinics of North America Equine Practice, v.34, n.2, p.253-276, 2018. Available from: <https://www.sciencedirect. com/science/article/pii/S0749073918300178>. Accessed: Feb. 20, 2021. doi: 10.1016/j.cveq.2018.04.004.

VALENTINE, B.A. Skeletal muscle. In: ZACHARY, J.F. Pathologic Basis of Veterinary Disease. $6^{\text {th }}$ ed. St. Louis: Elsevier; 2017. p.908-953. 